\title{
THE TASK OF MACHINE TOOL OPERATORS IN SMALL AND MEDIUM ENTERPRISES IN INDONESIA
}

\author{
Bernardus Sentot Wijanarka $^{1}$, Nuchron ${ }^{2}$, Dwi Rahdiyanta ${ }^{3}$, Theophile Habanabakize ${ }^{4}$ \\ 1,2,3 Department of Mechanical Engineering Education, Universitas Negeri Yogyakarta, Indonesia \\ ${ }^{4}$ College of Science and Technology, University of Rwanda, Rwanda \\ E-mail: bernadus_sentotw@uny.ac.id
}

\begin{abstract}
The needs of operators for each type of industry are different because the type and the complexity of the task is different. Small and medium-sized industries require machine operators with better capabilities than operators in large companies, thus it is necessary to identify what tasks are performed by these operators. This study aim at (1) identifying duties of machine tool operators in small and medium enterprises, and (2) identifying tasks carried out by machine tool operators in small and medium enterprises. This study used a descriptive research method. The participants were eight machine tool operators from five small and medium enterprises in Yogyakarta, Indonesia. The data collection used document review, observation, questionnaires and focus group discussions. The data were analysed using descriptive analysis. The results of the study were (1) five duties done by machine tool operators are identified (maintaining safe work environment, maintaining the machine tools, analyzing the blueprint, performing machining operations, cleaning the machines and the workplace), and (2) twenty seven tasks executed by machine tool operators are identified; twenty-two knowledge and skills, seventeen behaviors, and eighteen machines, tools and equipment required by machine operators.
\end{abstract}

Keywords: duties, machining, machine tool operators, small and medium enterprises, task

\section{INTRODUCTION}

Industrial services are industrial activities that serve the needs of others. In this activity, the raw materials are supplied by others while the establishments are paid as compensation for processing raw materials. Machining industry is a service industry that is implemented in microindustries, small industries, medium industries and large industries. The characteristics of each industry are different. Micro and small industries in the field of machinery typically reproduce the work of reparations and the making of simple components in small quantities but vary in their work. The mediumsized machining industry is a manufacturing industry of applied technology machines and simple machines in large quantities based on consumer orders. Large industries work on the manufacture of components or machines in mass quantities with sophisticated technology. The tasks of operators in small industries adjust to consumer orders with many variations. The type of work of machine operators in the midsized industry is usually only certain jobs and routine. Large industries in the field of machinery employ operators for sophisticated machines but only one type of routine works. Thus the needs of operators for each type of industry are different because the type of the task and the complexity of the task is different. Small and medium-sized industries require machine operators that have better capabilities than operators in large companies, thus it is necessary to identify what tasks are performed by these operators.

The need of workers for machine operators in Indonesia is very urgent because the number of machine tools made in the country and imports continues to increase. From 2010 until 2015, the trend of Indonesian machine tool imports continues to increase. Based on data from the Ministry of Industry, the import of Indonesian machine tools in 2010 reached the US \$480 million, while in that year machine tool export only reached the US \$ 100 million. In 2011, the import of machine tools reached the US \$ 770 million and exports reached the US \$ 50 million. As of June 2012, import of machine tools reached the US $\$ 500$ 
million while exports were not up to the US \$ 50 million. In 2013 the import of machine tools the US \$ 700 million. In 2014 imports of machine tools reached the US \$ 1.3 billion, exports only 10 percent. In 2015 imports of machine tools reached the US \$ 1.5 billion. Based on the data it can be seen that the trend of machine tool imports has always increased, thus it can be expected that the needs of machine tool operators increase with the increase of the number of machine tools.

Some research on task analysis has been done by many experts. The study by HyunSook, et al. (2012) was conducted to analyze the work of clinical research coordinators (CRCs). This study aims to find the tasks of CRC by using Dacum's job analysis method. After the CRC job is defined and the duties and tasks obtained are then validated twice, resulting in 12 duties and 78 tasks. Based on these results, it is also obtained tasks that are difficult to implement and tasks that are often done. Another study was conducted by Johnson (2010). This study aimed to arrange job analysis for Geospatial technicians in the United States. The study was conducted by The National Geospatial Technology (GeoTech) Center in order to support and validate the labor needs that require specific skills by The DOLETA's. Validation is done by implementing the Dacum job analysis method. Participants involved consisted of 8 GIS technicians. The research results have identified, ranked, and documented 55 task categories currently being implemented, 35 categories of skills and knowledge, and 27 attitude categories.

Dixon \& Stricklin (2014) conducted a job analysis to identify the competency profile of an entry-level CADD technician in North central Idaho. The created DACUM research chart consisted of 8 duty statements and 54 task statements. Lundkvist \& Gustavsson (2017) examined the learning and innovation process in SMEs. The research found employee driven innovations may take different forms and involve functions that can support innovative learning that goes beyond minor adjustments to the existing standards of production. Thus it can be said that workers in the industry can adjust production standards in the sense they are competent on their tasks and work.

Based on the results of the four studies above, it is evident that workers in the industry are well aware of their duties. Machine operators in small and medium industries do more complex jobs than large industrial machine operators. Operators in small industries do routine and non-routine jobs depending on consumer demand, while machine operators in large industries only work routine work. Thus, the job analysis for production machine operators in small and medium industries needs to be done. The objectives of this study were (1) identifying duties of machine tool operators in small and medium enterprises, and (2) identifying tasks carried out by machine tool operators in small and medium enterprises.

\section{METHOD}

This study used a descriptive research method. The study participants were eight machine tool operators from five small and medium enterprises in Yogyakarta, Indonesia. The name of the enterprises were Wahyu Workshop, Yayasan Dian Desa Workshop, PT. Jasatek, Bengkel Setia Workshop, Wangdi workshop. The methods of data collection were document review, observation, questionnaires, focus group discussion and interviews. Focus group discussion and validation involved 10 operators from five companies namely PT. MAK, CV. Karya Perkakas, PT. Jasatek, Setia Workshop, dan Wangdi Workshop. The data analysis used a descriptive analysis and a Dacum research chart.

\section{RESULTS AND DISCUSSION}

The manufacturing industry is an economic activity which processes basic goods mechanically, chemicals, or manually into final or intermediate goods, and or that goods of less 
value to higher value and nature closer to the end user. The activities also include services for manufacturing and assembling (BPS-Statistics of Indonesia, 2017).

The industrial sector in Indonesia is divided into 4 categories, namely (1) microindustry, (2) small industry, (3) medium industry, and (4) large industry. The category of the industry is determined based on the number of workers. The micro industry with the number of workers 1 to 4 people, the small industry with the number of workers 5 to 19 people, the medium industries with the number of workers 20 to 99 people, and the large industries with the number of workers 100 people or more. Based on data from the Central Bureau of Statistics (2017) from 2013 to 2015 the number of all business categories has increased. It is shown in Table 1.

\begin{tabular}{clccc}
\multicolumn{6}{l}{ Table } & Number of Industries in Indonesia \\
\hline No & Scale of & \multicolumn{3}{l}{ Year } \\
& industries & 2013 & 2014 & 2015 \\
\hline 1 & Micro & $2,887,015$ & $3,220,563$ & $3,385,851$ \\
2 & Small & 3,1351 & 284,501 & 283,022 \\
3 & Medium and & 23,698 & 24,529 & 26,322 \\
& Large & & & \\
\hline
\end{tabular}

Judging from the scale businesses that about 70.26 percent of the large and medium industries in Indonesia is a medium scale industry. Growth in the average total of Large and Medium Company from 2011 to 2015 was 3.05 percent. Since 2011, the growth of large industrial workforce and are experiencing positive growth, in 2012 amounted to 6.47 percent, in 2013 amounted 1.54 percent and in 2014 amounted 3.51 percent, in 2015 amounted to 1.29 percent. Contributions a large number of industrial workers from 2011 to 2015 an average of 86.63 percent while the industry was only 13.86 percent of the total large and medium industrial enterprises. The number of workers based on data from the Central Bureau of Statistics (2017) can be seen in Table 2.

Based on the above description, it can be expected that competent operator needs are very urgent in running the industry. The number of companies that are always increasing every year leads to an increase in demand for machine operators, as they are the main workers in the manufacturing industry.

Table 2. Number of workers at all industrial scales

\begin{tabular}{llccc}
\hline No & Scale of industries & \multicolumn{3}{c}{ Year } \\
& & 2013 & 2014 & 2015 \\
\hline 1 & Micro & $5,408,857$ & $6,039,855$ & $6,464,394$ \\
2 & Small & $4,325,254$ & $2,322,891$ & $2,271,387$ \\
3 & Medium and Large & $5,004,912$ & $5,180,531$ & $5,247,360$ \\
\hline
\end{tabular}

Based on observations and interviews with 8 operators obtained as many as 112 kinds of tasks they do in everyday activity. The tasks for each operator have similarities that need to be grouped. Based on discussions with operators all these tasks are then grouped into five duties, ie: (1) maintaining the safe work environment, (2) maintaining the machine tools (3) analysing the blueprint, (4) performing the machining process, and (5) cleaning machine tools, tools, and the workplace.

Based on the five groups of tasks (duties), they are then discussed again into a sequence of tasks for each duty. The result of the discussion was Dacum Research Chart consisting of 5 duties and 27 tasks. Each duty consists of several tasks. Details of the number of tasks are as follows (1) Duty A consists of 3 
tasks, (2) Duty B consists of 7 tasks, (3) Duty C consists of 4 tasks, (4) Duty 4 consists of 8 tasks, and (5) Duty 5 consists of 5 tasks. The complete results are Dacum Research Chart presented in Table 3.

In the Indonesian national competence standard, the competence unit of performing lathe operations contains 5 elements of competence, namely safety analysis, determining the requirements for the work, the process of forming the surface, the operation of the lathe, and checking the components to suit the specifications. The prerequisites for this competency unit are using hand tools, measuring by using measuring instruments, and reading technical drawings. The necessary knowledge according to the standard are engineering drawings, work safety, machining, and math theory. The unit of competency of performing milling process contains elements of competence similar to the performance of lathe operations. However, the competence unit of performing general machining has 6 units of competence with an additional set and maintain a machine.

Table 3. Dacum Research Chart of Machine Tool Operators

\begin{tabular}{|c|c|c|c|c|c|c|c|c|}
\hline \multicolumn{2}{|l|}{ Duties } & \multirow[b]{2}{*}{ A-2 } & \multirow[b]{2}{*}{ A-3 } & \multicolumn{2}{|c|}{ Tasks } & \multirow[b]{2}{*}{ A-6 } & \multirow[b]{2}{*}{ A-7 } & \multirow[b]{2}{*}{ A-8 } \\
\hline A & A-1 & & & A-4 & A-5 & & & \\
\hline $\begin{array}{l}\text { Maintain } \\
\text { safe work } \\
\text { environment }\end{array}$ & $\begin{array}{l}\text { use } \\
\text { wearpack }\end{array}$ & $\begin{array}{l}\text { use safety } \\
\text { glasses }\end{array}$ & $\begin{array}{l}\text { check } \\
\text { safety } \\
\text { equipment } \\
\text { on the } \\
\text { machine }\end{array}$ & & & & & \\
\hline $\begin{array}{l}\text { B maintain the } \\
\text { machine } \\
\text { tools }\end{array}$ & $\begin{array}{l}\text { B-1 } \\
\text { maintain } \\
\text { proper fluid } \\
\text { levels }\end{array}$ & $\begin{array}{l}\text { B-2 } \\
\text { change } \\
\text { machine oli/ } \\
\text { coolant }\end{array}$ & $\begin{array}{l}\text { B-3 } \\
\text { check all } \\
\text { the } \\
\text { machine } \\
\text { operations } \\
\text { panels }\end{array}$ & $\begin{array}{l}\text { B-4 } \\
\text { check the } \\
\text { rotation } \\
\text { of the } \\
\text { spindle }\end{array}$ & $\begin{array}{l}\text { B-5 } \\
\text { maintain } \\
\text { automatic } \\
\text { equipment }\end{array}$ & $\begin{array}{l}\text { B-6 } \\
\text { prepare } \\
\text { the } \\
\text { auxiliary } \\
\text { tools }\end{array}$ & $\begin{array}{l}\text { B-7 } \\
\text { perform } \\
\text { minor } \\
\text { repair }\end{array}$ & B-8 \\
\hline $\begin{array}{l}\text { C } \\
\text { analyze } \\
\text { blueprint }\end{array}$ & $\begin{array}{l}\text { C-1 } \\
\text { identify the } \\
\text { material } \\
\text { use }\end{array}$ & $\begin{array}{l}\mathrm{C}-2 \\
\text { identify } \\
\text { dimensions }\end{array}$ & $\begin{array}{l}\text { C-3 } \\
\text { identify the } \\
\text { measureme } \\
\text { nt tools }\end{array}$ & $\begin{array}{l}\text { C-4 } \\
\text { develop } \\
\text { the work } \\
\text { sequence }\end{array}$ & C-5 & C-6 & C-7 & C-8 \\
\hline $\begin{array}{l}\text { D } \\
\text { perform } \\
\text { machining } \\
\text { operations }\end{array}$ & $\begin{array}{l}\text { D-1 } \\
\text { mount the } \\
\text { cutting } \\
\text { tools }\end{array}$ & $\begin{array}{l}\text { D-2 } \\
\text { mount the } \\
\text { workpiece }\end{array}$ & $\begin{array}{l}\mathrm{D}-3 \\
\text { operate the } \\
\text { machine } \\
\text { tools }\end{array}$ & $\begin{array}{l}\mathrm{D}-4 \\
\text { monitor } \\
\text { the tools } \\
\text { and } \\
\text { machine }\end{array}$ & $\begin{array}{l}\text { D-5 } \\
\text { check the } \\
\text { dimensions } \\
\text { of the } \\
\text { product }\end{array}$ & $\begin{array}{l}\text { D-6 } \\
\text { replace } \\
\text { worn } \\
\text { cutting } \\
\text { tools }\end{array}$ & $\begin{array}{l}\text { D-7 } \\
\text { perform } \\
\text { finishing } \\
\text { operations }\end{array}$ & $\begin{array}{l}\text { D-8 } \\
\text { measure } \\
\text { the } \\
\text { finished } \\
\text { product }\end{array}$ \\
\hline $\begin{array}{l}\text { E } \\
\text { clean } \\
\text { machine and } \\
\text { workplace }\end{array}$ & $\begin{array}{l}\text { E-1 } \\
\text { clean } \\
\text { machine } \\
\text { tools }\end{array}$ & $\begin{array}{l}\text { E-2 } \\
\text { clean the } \\
\text { cutting tools }\end{array}$ & $\begin{array}{l}\text { E-3 } \\
\text { clean } \\
\text { workplace }\end{array}$ & $\begin{array}{l}\text { E-4 } \\
\text { maintain } \\
\text { machine } \\
\text { condition }\end{array}$ & $\begin{array}{l}\text { E-5 } \\
\text { shut down } \\
\text { the } \\
\text { machine }\end{array}$ & E-6 & E-7 & E-8 \\
\hline
\end{tabular}

The work to be done by a production machine operator in a small to medium enterprises is different from the competency standard of the machine operator according to the Indonesian National Competency Standards. The tasks of machine operators in the small and medium-sized industries are more complicated and more complete than those described in the standard. In the competency standard, the competency unit of the machine operator is a unit that describes the activities of working with the machinery which includes the activities of conducting safety, determining the work needs according to drawings and specifications, 
installing the work piece, operating the machine based on machining parameters and safety procedures, and measuring components according to specifications. The important work that operators do based on the results of the study is maintaining the machine. Thus it can be said that the activities of routine maintenance and repair are done by the operator. In addition, the responsibility for the condition of the machine, cleanliness of the machine and the work environment becomes the duty of the operator as well.

The operator tasks that have been generated above still consist of several steps, but the steps are not described here because they are very specific according to the type of machine being operated. In order to carry out its duties, operators must also possess the knowledge that underlies the execution of the task. Such knowledge is required as the theoretical basis of each task undertaken. In addition, when the operator performs his work, the operator must have an appropriate attitude in the implementation of his duties as an operator. Thus the operator's competence includes attitude, knowledge, and skills.

As an integral part of this research process, it was also conducted observations and interviews about the machines and tools used. The machine is the main tool in carrying out the work, while the tool is additional equipment in carrying out machining operations. The ability to operate tools and machines supports performance across the entire duties of machine operators.

The competence of an operator includes the areas of attitude, the knowledge, and skills. The knowledge that must be known by the machine operator is an integral part of the tasks of production machine operators. The knowledge that must be known by the production machine operators are: (1) reading blueprint, (2) material science, (3) metrology (calipers), (4) geometric dimensioning and tolerancing (GD\&T), (5) gages, (6) machining technology (speed and feed), (7) lubrication Oil (8) lubrication System, (9) basic shop Bath (10) management of production, (11) maintenance and repair of machine, (12) the machine elemen, (13) hand tools knowledge (14) bench work, (15) machine tools construction (16) cutting tools, (17) cost of machining (18) machine tools control, (19) electrical wiring, (20) process planning, (21) quality Control, and (22) safety knowledge.

Based on the results of the discussion, there is an appropriate knowledge and skills gap required by operators and applicable competency standards in Indonesia (Ministry of Manpower and Transmigration of Indonesia, 2004). Based on the analysis of tasks by the operator obtained 22 kinds of knowledge, whereas according to the standard of competence only 4 kinds. Thus it can be concluded that the applicable competency standards should be reviewed or revised in accordance with conditions at work.

Such knowledge is required immediately when an operator performs his work, for example when making a thread, he must have knowledge of the shape of the thread, the threaded dimension, the shape tolerance, the size tolerance, the thread measurement and the quality of the thread. Without such knowledge, an operator cannot plan the manufacture of the product.

Competence includes three domains: knowledge, skills, and attitude. Behavior is a competency in the domain of attitude. Competence in the domain of attitude must be owned by both workers and prospective workers in the industry at the moment (Baser et al., 2017).

Behaviour is a component of a machine operator's competence that must be demonstrated when performing. The necessary behaviors can be identified from interviews with operators and observations when operators carry out their work. The required work behavior based on task analysis compared to Indonesian national competence standard can be seen in Table 4. Based on the results of the task analysis process, it can be seen that the behavior of a production machine operators is 
more complete than those in the competency standard. Thus the results of task analysis are more appropriate as a material of curriculum preparation in vocational schools, community colleges, and polytechnics.

Behavior required by machine operators according to the results of interviews and observations are relatively numerous (17 kinds). Behavior required in the standard of competence is only 4 kinds. Attitudes to competency standards are only suitable for workers who perform routine tasks and only one type of work. Operators in small and medium industries require more complex attitude competencies because they always adapt to the types of jobs that are constantly changing and not routine. Baser et al. (2017) states that a high awareness of the importance of these skills (adaptive skills, critical thinking skills, and problem-solving skills) will help students to master the skills perfectly. It can also be used as a guide for students to identify elements and features that are required by employers nowadays. Thus, it can be concluded that there is relevance between the research results and the conditions of readiness of students to work in the industry.

Table 4. The Behavior of the Operator between the Task Analysis and Competency Standard

\begin{tabular}{lll}
\hline No & \multicolumn{1}{c}{ Task Analysis } & \multicolumn{1}{c}{ Indonesian National Competency Standards } \\
\hline 1 & Able to communicate & Communicating ideas and information \\
2 & Creative & - \\
3 & Punctual & Working with other people and groups \\
4 & Team player & - \\
5 & Work safety & \\
& & Plan and organize activities \\
6 & Work according to work instructions & - \\
7 & Maintain cleanliness & - \\
8 & Precision & Solve the problem \\
9 & Able to solve the problem & - \\
10 & Honest & - \\
11 & Aware of quality & - \\
12 & Responsible & - \\
13 & Reliable & - \\
14 & Innovative & - \\
15 & Accurate & - \\
16 & Analytical & - \\
17 & Patient &
\end{tabular}

Data on machines and tools used by machine operators are obtained from observations and interviews. Tools, equipment, and machines are needed by the operator in order to work optimally and efficiently. Required tools include machine tools as the main and additional tools as supporting work processes. Machines, equipment, and tools required are (1) Turning Machine, (2) Milling machine, (3) Drilling machine, (4) Tool grinding machine, (5) Vernier caliper, (6) Micrometer, (7) Machine attachment, (8) Cutting tools for turning, (9) Cutting tools for milling, (10) Twist drill, (11) Knurling, (12) Reamer, (13) Block gauge, (14) Angle gauge
(15) Dial indicator, (16) Hand tools (file, hacksaw, hammer, wrench, spanner, Allen key, screwdriver), (17) Jigs and fixtures, and (18) Machine vise.

The manufacturing industry is currently using computer-controlled machine tools (CNC). This CNC machine is mainly used to make new machine element which is the mass product. Not many small industries have $\mathrm{CNC}$ machines, because of their wide variety of work, however for future needs knowledge of CNC machine tool automation is required by operators. Certification and mastery of English is a requirement for experienced workers and new workers. Competence certificates are now 
mandatory for all workers, either competency certificates issued by professional certification bodies or by professional associations at national, regional or international levels. Mastery of English becomes very important in order to face globalization and free trade between countries. In addition, it is expected that workers can work around the world because it has a certificate of competence and English language skills.

Facing the $4^{\text {th }}$ industrial revolution, it seems that Indonesia is not ready yet. It can be seen from almost all companies in Indonesia is still dominated by labor-intensive enterprises with the reason that the population is large and the workforce is abundant in number. Pardede (2017) said that Indonesia is still in the old industry, we still use low and middle skills. We need a lot of work, our process is mostly analog, but we have to go into the digital industry. The problem is, this fourth industrial revolution is also distractive.

\section{CONCLUSION}

Based on the results of research and discussion, it can be concluded as follows: (1) five duties done by the machine tool operator are identified (maintaining safe work environment, maintaining the machine tools, analyzing the blueprint, performing machining operations, cleaning machines and the workplace), and (2) twenty seven tasks executed by the machine tool operator are identified; twenty two knowledge and skills; seventeen behaviors; and eighteen machines, tools, and equipment required by machine operators.

\section{REFERENCES}

Baser, J.A., Jizat, N.A.M., Yunus, F.A.N., Rahim, M.B., Razzaq, A.R.A., \& Hasan, A. 2017. Competency of National Dual Training System Industry Advisors. Jurnal Pendidikan Teknologi dan Kejuruan, 23.4, 328-338
Baser, J.A., Hasan. A., Asha'ri, A.H., \& Khairudin, M. 2017. A Study on The Transferable Skills of The Engineering Students at Universiti Tun Hussein Onn Malaysia. Jurnal Pendidikan Teknologi dan Kejuruan, 23.3, 257-264

BPS-Statistics of Indonesia. 2017. Indikator Industri Manufaktur - Manufacturing Industrial Indicator Indonesia 2015. Jakarta: BPS

Dixon, R. A. \& Stricklin, L.S. 2014. Lessons Learned Using the Modified DACUM Approach to Identify Duties and Tasks for CADD Technicians in North Central Idaho, Online Journal for Workforce Education and Development, VII,1 Spring.1-14

Hyun-Sook, K., Haeng-Mi, S., Nan-Young, L., Kyung-Sook, C., Sung-Bok, K., Yeo-Jin, Y., \& Young-Sook, C. 2012. Job Analysis of Clinical Research Coordinators Using the DACUM Process. J Korean Acad Nurs. 42.7, 1027-1038

Johnson, J. 2010. What GIS Technicians Do: A Synthesis of DACUM Job Analyses. URISA Journal. 22.2, 31-40

Lundkvist, A.H. \& Gustavson, M. 2017. Conditions for Employee Learning and Innovation Interweaving Competence Development Activities Provided by a Workplace Development Programme with Everyday Work Activities in SMEs. Vocations and Learning, 1-19

Ministry of Manpower and Transmigration of Indonesia. 2004. Keputusan Menteri Tenaga Kerja dan Transmigrasi No. Kep. 240/Men/X/2004, Tentang Penetapan Standard Kompetensi Kerja Nasional Indonesia Sektot Logam Mesin

Pardede, R. 2017. Indonesia Hadapi Revolusi Industri Keempat. News. Jakarta: Ministry of Industry of Indonesia 